MANAGEMENT AND MARKETING

\title{
ORGANIZATION OF EFFECTIVE AND QUALITATIVE CUSTOMS SERVICE SYSTEM
}

\author{
Zh. A. Tashiev, Candidate for Phd, BFEA, Kyrgyzstan \\ T.Sh.Abdyrov, Doctor of Economics, Professor, Kyrgyzstan
}

DOI: https://doi.org/10.31435/rsglobal_ws/31032019/6412

\section{ARTICLE INFO}

Received: 13 January 2019

Accepted: 19 March 2019

Published: 31 March 2019

\section{KEYWORDS}

customs services, foreign economic activity, object, subject, control system, the quality of customs services. quality management, International Organization for Standardization, customs authorities, participants of foreign economic activity, customs representatives.

\begin{abstract}
Improvement of customs operations should be carried out primarily through the improvement of the quality management of customs services. Quality management of customs services is carried out within the existing management system of the customs authorities.
\end{abstract}

Citation: Zh. A. Tashiev, T. Sh. Abdyrov. (2019) Organization of Effective and Qualitative Customs Service System. World Science. 3(43), Vol.3. doi: 10.31435/rsglobal_ws/31032019/6412

Copyright: (C) 2019 Zh. A. Tashiev, T. Sh. Abdyrov. This is an open-access article distributed under the terms of the Creative Commons Attribution License (CC BY). The use, distribution or reproduction in other forums is permitted, provided the original author(s) or licensor are credited and that the original publication in this journal is cited, in accordance with accepted academic practice. No use, distribution or reproduction is permitted which does not comply with these terms.

The present Article considers customs activities quality management matters. To achieve this, serious work on professional training of customs bodies personnel, creating conditions for its activation should be carried out and, most importantly, the personal interest of the top management of the customs service and customs authorities in this matter, understanding of what customs bodies , performance quality means and desire to take personal control of its implementation are needed.

In modern conditions, quality management is a certain strategy and tactics not only for survival, but for further prosperity of the entire society and specific organizations.

Quality management originated as objective need of mankind, initially - for a high-quality product and technology, for highly qualified personnel, and then - as a need for decent life quality.

New elements have been introduced into the quality management rules and requirements for integrating activities of various organizational services and units have been strengthened with time. On top of that, the TQM, meaning total quality management, has appeared and is still developing. It should be noted that management is divided into functional components, and theoretically it represents goal-specific management. The main idea is to structure and develop goals, and then design a system for those goals achievement organization and motivation.

Quality management is understood as an effect on a certain process to ensure the required quality. Such understanding of management covers the following elements: the subject of management, the object of management and influence process itself.

Quality management is implemented through management functions. Process approach to management allows organizing and presenting quality management as a continuous chain of logically interrelated functions that effect on production to ensure quality. 
When the process approach is used in enterprise management, the following functions shall be used: concluding transactions, decision making, planning, organizing, motivating, recruitment, disposal, controlling, communicating, researching, evaluating, coordinating etc.

Quality management process is related to external environment, to customers and sales markets. Quality is planned based on that policy. Then work is organized to achieve the required quality in the production process through allocation of required resources, personnel is trained and encouraged. Further, quality is controlled and obtained information is analyzed. Following the analysis, a set of relevant measures is developed and management decisions are taken.

The International Organization for Standardization (ISO) interprets quality as a set of properties and characteristics of products (services) that ensure that statutory and supposed needs are met. Since needs can be public and individual, then approaches to quality management must also be different. Actually it is the government that much ensure that such public needs as environmental protection, saving energy and materials, security are met.

Customs bodies of Kyrgyzstan have passed two stages in their development since the early 1990: "Customs for customs "and "customs for government"- and has been recently improved to the third stage - "customs for participants of foreign economic activity (FEA)", which main feature is the quality of customs service.

Quality of customs services is a combination of characteristics of customs services, which identifies whether these services are capable to meet the needs of FEA participants (for execution of a set of actions by customs bodies and persons engaged in customs activities to ensure that goods and vehicles cross customs borders of States) when goods are moved from a seller to a customer as required by those states ${ }^{1}$.

To make the quality of customs activities controllable, it is necessary to determine:

- the ideology of customs processes quality management as a main principle of activity;

- the methodology of customs activities quality management as a way of managing it;

- method of customs activities quality management as a practical method of management;

- management technologies as direct working processes for implementation of customs activities management functions.

The ideology of customs activities quality management is to meet the requirements of a customer for customs functions and of customs service deliverables consumer - participants of FEA.

Customs activities quality management methodology and method are based on those of domestic and international experience in quality management.

The management system assumes inclusion of a set of acting legislative, policy, regulatory and technological documents in it. The set of legislative, policy and industry regulatory documents covering customs bodies is supplemented by a mechanism for systematic revision, updating of that set and simplification of customs procedures.

See the Figure 1 to find structure of the customs authorities management system made depending on the work products quality criteria.

To become familiar with theoretical foundations of customs activities quality management in the customs service, serious work on professional training of customs bodies personnel, creating conditions for its activation should be carried out and, most importantly, the personal interest of the top management of the customs service and customs authorities in this matter, understanding of what customs bodies performance quality means and desire to take personal control of its implementation are needed.

Introduction of quality standards of customs activities that meet modern international requirements and mechanism of responsibility of the management for doing so shall greatly expedite solution of the given issue.

Quality of customs service is determined not only by the quality of customs structure's activities but also by the quality of performance of organizations of the entire customs field.

A customs representative can become a competitive participant in the market of customs services only by improving the quality of customs services. In the context of modern business, competitiveness of any enterprise regardless of its size is determined primarily by the quality of its services and whether price for them can be compared with proposed quality. Quality management is dictated by today's time, since this knowledge is vital in a market economy by implying intense competition between service providers. Thus, quality management is currently the main direction that ensures success and requires that all management objectives should be achieved.

1 O.A. Starkova Customs services quality management: thesis ...Ph.D. in Economics Saratov: Saratov State Social and Economic University 2007 


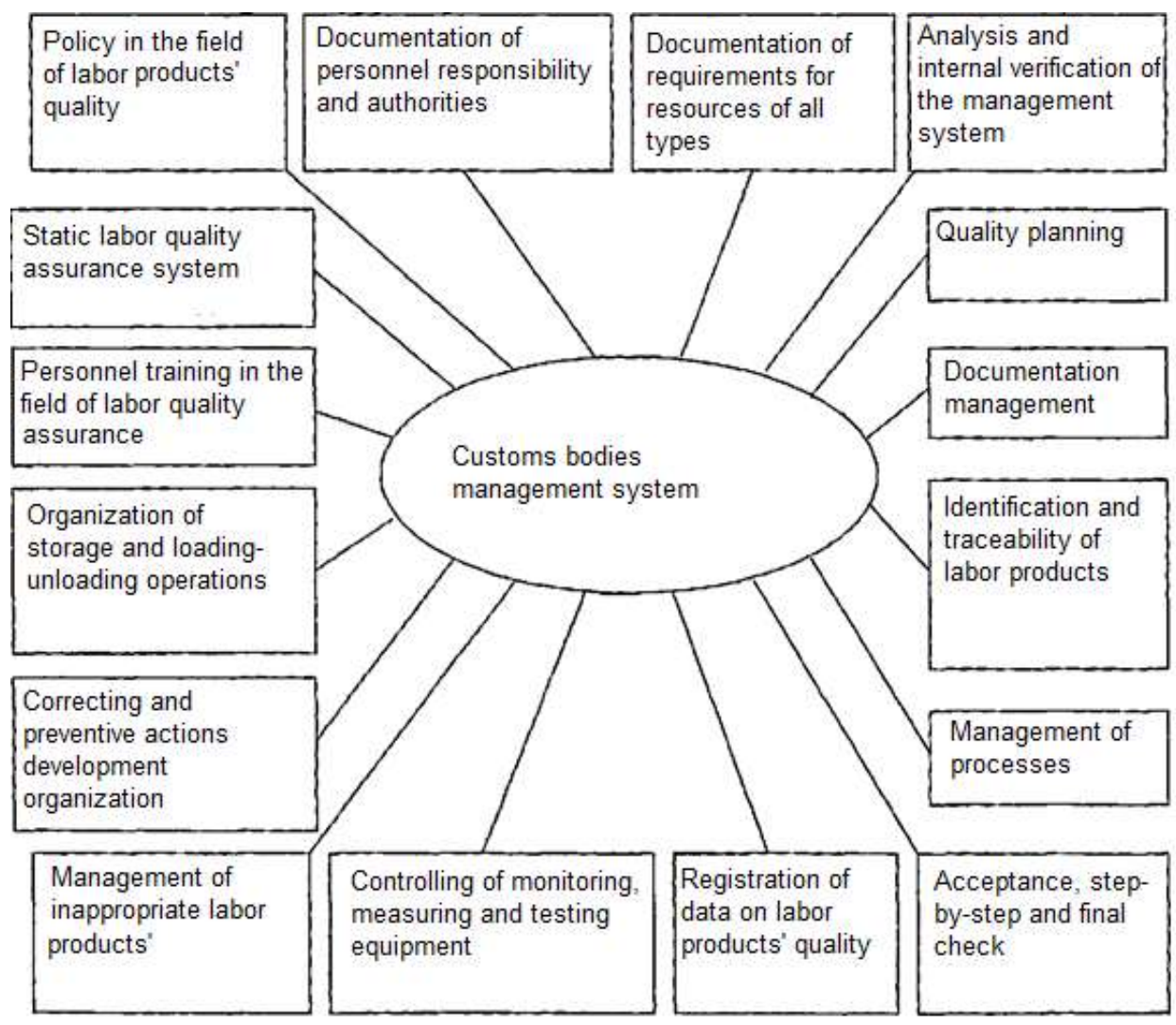

Fig. 1. Structure of the customs bodies management system

Improvement of customs services directly depends on improvement the level of quality of provided customs services in view of interests of participants in foreign trade activity.

Quality management contains a number of principles that must be taken into account upon concept definition (see Table 1).

Table 1. Quality principles

\begin{tabular}{|l|l|l|}
\hline ser. \#. & Name of the principles & Content of the principle \\
\hline 1 & Consumer orientation & $\begin{array}{l}\text { An organization depends on its customers, therefore it should } \\
\text { understand current and future needs of consumers, meet their } \\
\text { requirements and try to exceed their expectations. }\end{array}$ \\
\hline 2 & Leadership of a head & $\begin{array}{l}\text { A head determines the unity of purpose and areas of activities } \\
\text { of the organization. Therefore, it is necessary to create and } \\
\text { maintain internal environment in which employees can } \\
\text { become fully involved in activities to achieve the } \\
\text { organization's goals. }\end{array}$ \\
\hline 3 & Involvement of personnel & $\begin{array}{l}\text { Employees of all levels determine the essence of the } \\
\text { organization, and their full involvement makes it possible to } \\
\text { use their abilities for the benefit of the organization. }\end{array}$ \\
\hline 5 & $\begin{array}{l}\text { The desired result is more efficiently achieved if activities and } \\
\text { associated resources are managed as a process. }\end{array}$ \\
\hline 6 & Systemic approach & $\begin{array}{l}\text { Identification, understanding and management of interrelated } \\
\text { processes as systems contribute to performance and } \\
\text { effectiveness of the organization in achieving its objectives. }\end{array}$ \\
\hline 7 & Reliability of facts used & $\begin{array}{l}\text { Continuous improvement of the entire organization should be } \\
\text { considered as its immovable purpose. }\end{array}$ \\
\hline 8 & $\begin{array}{l}\text { Effective solutions are based on the analysis of data and } \\
\text { information }\end{array}$ \\
\hline Mutually & beneficialionships with suppliers & $\begin{array}{l}\text { Organization and its suppliers depend on each other, and } \\
\text { mutually beneficial relations between them enhance the ability } \\
\text { of both parties to create values. }\end{array}$ \\
\hline
\end{tabular}


Quality of service may greatly vary depending on who, when, where and how it is rendered, because a service production and consumption process is related to participation of people. It should be noted that a quality of service is very difficult to control. A quality of services provided by different or even the same specialist varies depending on his/her physical form and mood during communication with each consumer. Therefore, service industry organizations undertake various quality control measures - careful selection and training of staff, increasing employee motivation by applying incentives directly related to the quality of services provided, introduction of detailed and standardized work procedures. Direct contact of employees with consumers also increases the degree of responsibility of employees for the quality of the service provided. A service provider must constantly monitor customers' satisfaction degree through surveys and suggestion-and-complaint system.

Another element of improving quality and reducing risks is relying on the international quality standard ("quality loop"- ISO-9000).

The "quality loop "of customs activity is the set of all customs service's lifecycle phase from its initial definition to implementation in the process of customs activity. These stages consist of:

- $\quad$ customs activities marketing;

- $\quad$ designing (development) of customs services;

- $\quad$ preparation and development of customs technology;

- material and technical support for implementation of customs services;

- $\quad$ rendering (production, sale) of customs services;

- $\quad$ controlling of how well customs service is provided;

- $\quad$ analysis of customs service usage effectiveness;

- $\quad$ adjustment of the customs service's content (hereinafter - cycle repetition).

The "quality loop "of the customs service can be represented as a spiral in simplified form, which looks like as follows in plan (Fig. 2).

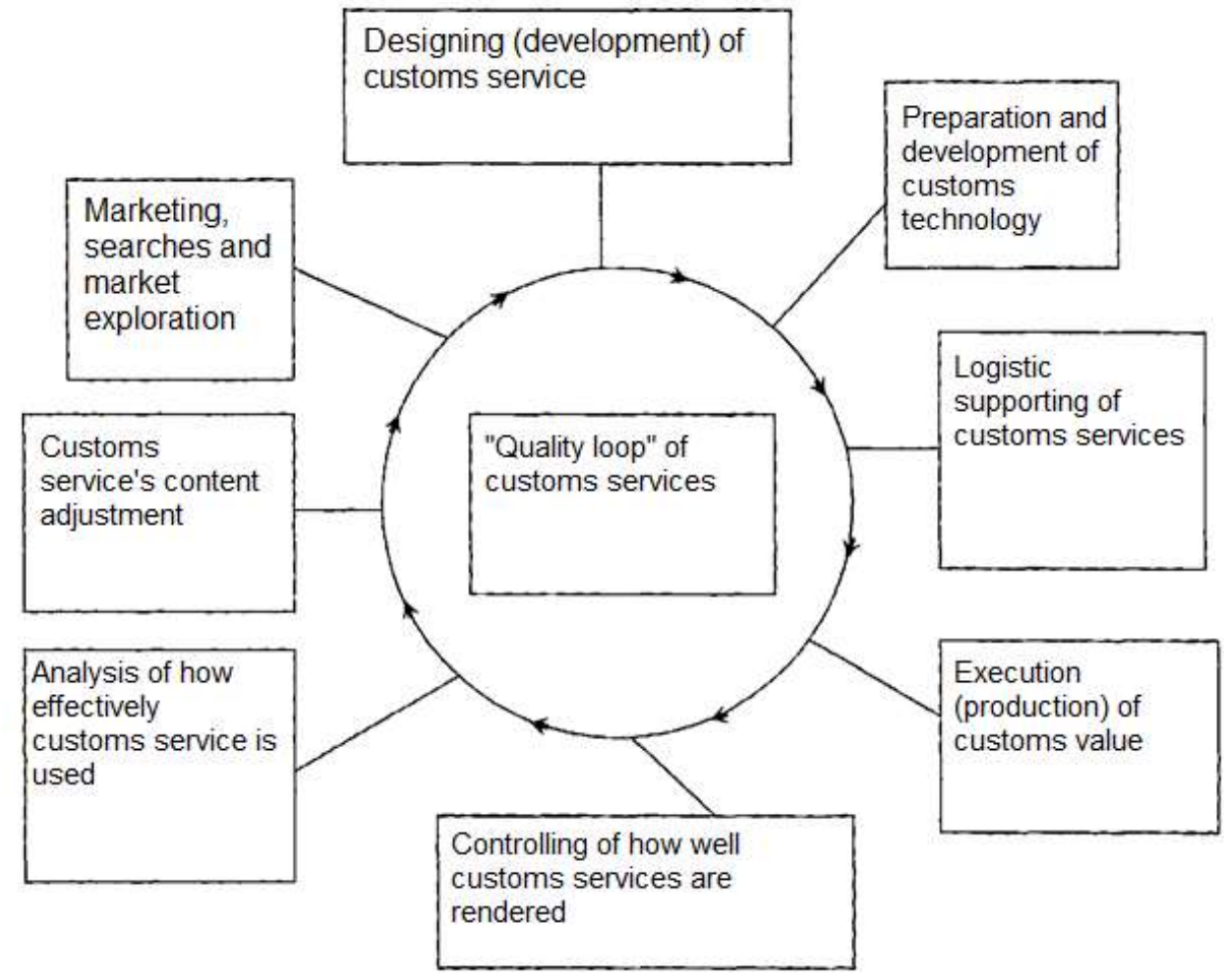

Fig. 2. "Quality loop "of the customs service

This standard facilitates relationships between the representatives of the service rendering organization and the consumer organization by describing certain elements, possible requirements for each element and entire service. These clear requirements allow executors to identify and determine the possibility of improving each service's quality at all stages of its formation and provision, simultaneously evaluating and systematizing the risks, making the service more structured and 
manageable. Possibility emerges for a consumer to reduce the risk of obtaining undesirable elements and factors while using required service.

The main goal of the quality system built based on the ISO 9000 standards is to ensure the quality of products and services required by a customer and to provide him with evidence of enterprise's ability to do so. Quality requirements is expression of certain needs or their translation into a set of quantitatively or qualitatively established requirements for an item's characteristics to make it possible to implement and verify them.

Thus, effective quality management system in customs sphere organizations should be formed based on standards and professionalism of customs specialists.

Despite that customs activities are strictly regulated by international standards and agreements, it is advisable to use innovations widely as a means of obtaining certain competitive advantages of customs organizations.

Only high professionalism of specialists in customs clearance and creative way of thinking enable to use innovations more effectively in the context of existing rules and standards.

\section{REFERENCES}

1. Всеобщее управление качеством: Учебник для вузов / Под ред. О.П. Глудкина. - М.: «Радио и связь», 1999.г

2. Большая Российская энциклопедия. - М.: Эдди-Пресс, 2001. - 870 с.

3. Большая советская энциклопедия: В 30 т. - Режим доступа: http://bse.sci- lib.com (дата обращения 05.09.21) 01

4. ИСО 9000:2005 Системы менеджмента качества. Основные положения и словарь. - Режим доступа: http://www.iso.org/iso/ru/home/store/ catalogue_tc/catalogue_detail.htm?csnumber=42180

5. Гупанова Ю.Е. Концептуальные и методологические основы оптимизационно-адаптивного управления качеством таможенных услуг в условиях неопределенности и риска: Монография. - М.: Изд-во РТА, 2011. - 106 с.

6. Ершов А.Д., Евдокимов А.И., Доля А.Н. Теория и методология формирования «сервисной таможни»: Монография. - СПб.: Изд-во СПб филиала РТА, 2005. - 203 с.

7. Макрусев В.В., Сафронов А.В. Государственные таможенные услуги: Монография. - М.: Изд-во PTA, 2008. - $196 \mathrm{c}$.

8. Таможенные услуги в международной цепи поставки товаров: Монография / А.Д. Ершов, В.В. Макрусев, О.В. Калинина, К.А. Сизова. Под общ.ред. В.А. Черных. - М.: РИО РТА, 2007. - 244 с.

9. Калинина О.В. Организационно-экономический механизм совершенствования таможенного сервиса внешней торговли в условиях риска: Дис. ... канд. экон. наук. - СПб., 2006. - 196с. 